\title{
The Effect of Management Policy \& Process on Adopting Entrepreneurship Aspects by Jordanian Universities
}

\author{
Firas Rifai ${ }^{1} \&$ Abdul Sattar H. Yousif ${ }^{1}$ \\ ${ }^{1}$ Faculty of Economics and Administrative Sciences, Al-Zaytoonah University, Amman, Jordan \\ Correspondence: Firas Rifai, Faculty of Economics and Administrative Sciences, Al-zaytoonah University of \\ Jordan, Amman, Jordan. E-mail: frifai@gmail.com
}

Received: August 12, 2016

Accepted: August 25, 2016 Online Published: August 29, 2016

doi:10.5539/jms.v6n3p127

URL: http://dx.doi.org/10.5539/jms.v6n3p127

\begin{abstract}
This paper aims at exploring the role of the university managerial systems and policies in the process of implementing the concept of entrepreneurship and innovation by Jordanian universities. A questionnaire was used as a means of data collection. Seven Jordanian universities were chosen from both governmental and private sectors and 320 questionnaires were distributed to a random sample of managerial staff of these seven universities. The resulting data was carefully viewed, audited and statistically analyzed using the most appropriate statistical tests. The outcomes and results of the statistical analysis clearly indicated that the three independent variables (i.e. The university managerial process related to conducting the entrepreneurial concept implementation problems and obstacles, the university general managerial and financial policies and managerial staff awareness of entrepreneurial aspects) had a positive impact on both dependent variables individually and collectively (i.e. university expansion and the consolidation of university competitive advantage).
\end{abstract}

Keywords: university managerial process, university policy, entrepreneurship aspect

\section{Introduction}

Improving the implementation process of entrepreneurship aspect by universities has never been more necessary than now. Paying extra attention to entrepreneurship activities and projects at schools, educational institutions and universities would yield a positive return to the national economy dynamism. Beyond its considerable contribution to the creation of new social enterprises and releasing new business, educational entrepreneurship implementation would provide additional employment opportunities for young people. This would surely help them to be more creative and productive at work.

Therefore, it might be relevant to suggest that investing in educational entrepreneurship practices would yield a worthy return socially and economically. Many field studies have affirmed that pupils and students, who have participated in entrepreneurial activities, are three to six times more likely to start their own business later on in their life, in comparison with those who did not receive or partake in any entrepreneurship program (European Commission, 2013).

The increasing importance of entrepreneurship and innovation to the national economy and society has motivated researchers to be more concerned with educational entrepreneurship to prepare a new generation of young entrepreneurs. Educational entrepreneurship, actually, helps students to acquire necessary entrepreneurial attributes, encouragement, knowledge, and other essential skills to be able to lunch a successful venture business in the future (Cho, 1998).

It might be substantial to note that educational entrepreneurship is not a universal concept. Therefore, it should be implemented in compliance with the national culture context of each individual country (Lee \& Peterson, 2000). In the same context, the local government of the Japanese capital city, Tokyo, has officially announced its plan to commence an education entrepreneurship program directed to high school students for the first time in January 2001. In South Korea, only a few colleges have developed entrepreneurship curriculum with the majority of colleges offering entrepreneurship related courses as a part of the requirements for the fulfillment of general education qualification (Sang et al., 2005).

One of the top priorities of universities is how to encourage and promote entrepreneurship. Universities and other educational institutions are concerned with helping their graduates acquiring the necessary entrepreneurial 
vision. The fruit of that is the expansion of an entrepreneurship curriculum and providing more entrepreneurial promotion and patronizing centers in many universities round the world (Rifai, 2015). Upholding entrepreneurship has become one of the main priorities of the public policy (Luthje \& Franke, 2003).

The majority of world governments are increasingly concentrating on the role of universities in providing societies with qualified entrepreneurs and generating new innovative ideas to smooth out the process of establishing new businesses. This would contribute significantly to the goal of increasing national wealth and society (Rifai, 2015).

The resent statistics have brought to light that entrepreneurship education has been widely refereed in academic journals and over 100 established centers (Finkle et al., 2006).

\section{Literature Review}

Entrepreneurship is an old concept, first defined by Richard Cantillon (1755) as a combination of materials, money and work brought to market as a formation of a new company (cited in: Wickham, 2001, p. 19). According to Adam Smith (1776), entrepreneurship comprises human activities that lead to changes in the pattern of the prevailing division of labor, as noted by Steven Michel (2008). Also, Karl Marx under historical determinism, tended to ignore or diminish entrepreneurs by minimizing the importance of the individual in history and economics (Isaac, 1998).

According to Schumpeter (1934), entrepreneurship is a process of change through the introduction of a new product, process, way, market, and a new source of raw material for processing. In this way, entrepreneurs are the makers of the economy and are constantly evolving. Kirzner (1985) of the Chicago School of Economics, suggested that entrepreneurship is awareness of untapped opportunities in current market conditions (Najim et al., 2014).

The importance of entrepreneurship education was discussed by many authors and researchers: by Allan Gibb (2002) at UK level, and by Garavan \& O'Cinneide (1994a, b) at a European level; by Gorman et al. (1997) in a ten-year study; by Hannon (2004) in creating foundations for the subsequent National Council for Graduate Entrepreneurship (NCGE) initiatives; by Matlay \& Carey (2007) through a ten-year longitudinal study from 1995-2004; by Pittaway \& Cope (2007); and by Pittaway \& Hannon (2008) in assessing institutional strategies for Higher Education (HE) enterprise education (Rae et al., 2012, p. 382).

Many authors have debated the purpose, goals, values and pedagogies of education enterprise. This can be summarized as follows:

1) Lewis (2011) concluded that entrepreneurship struggled to gain academic legitimacy at a moral, pedagogical and theoretical level, with the quality and focus of research being constraint. Controversially, Lewis asserted that the unresolved tension of the twin goals of enabling students to become entrepreneurs or to understand and operate within an enterprising society,

2) Blenker et al. (2011) proposed a progression from existing paradigms of education to a new one of "facilitating entrepreneurship as everyday practice,

3) Jones (2011) argued the importance of entrepreneurship education being underpinned by an explicit teaching philosophy grounded on student learning,

4) Jones \& Matlay (2011) developed a conceptual framework centered on the student and their dialogic relationships with educator, institution, educational processes and community.

5) Carey \& Matlay (2012) have reported about emergent issues and challenges facing educators,

6) Rae (2010) proposed that a "new era" of responsible entrepreneurship and related education was required to address the failures of a market capitalistic entrepreneurship which contributed to the financial crises of 2008-2011.

However, to stimulate student and graduate entrepreneurship, higher education institutions have been playing a significant role and can play an important role in educating and encouraging the entrepreneurs of the present and future to be a more effective generation (Rae et al., 2012, p. 381).

To introduce entrepreneurial education and encourage innovation in universities, managers and decision makers should have the ability to conduct such a radical change. Based on the related literature of management and organization theory (Burns \& Stalker, 1961; Daft, 2007; Schermerhorn, 2008) it would be possible to generally postulate the typical characteristics of low (poorly) innovative organizations (Zlatko \& Vojko, 2013, p. 37).

Based on the published information and statistics the characteristics of less innovative organizations, it can be 
said that one of the crucial reasons for lagging behind most developed and innovative organizations is the tendency to preserve the traditional working practices and the lack of innovativeness (Dyck \& Mulej, 1998; Bučar \& Stare, 2002; Mulej, 2006).

Thus, less innovative organizations lagged behind, due to a very slow transformation process from traditional to innovative working systems (Mulej \& Kajzer, 1998; Newman \& Nollen, 1998; Mulej, 2006). Therefore those less inventive organizations must enhance their innovativeness to be more pioneering. The essential and most important goal is moving beyond traditional working practices and thinking of how to be more innovative. The desired changes would trigger numerous changes in working practices, attitudes and behavior of all the employees in the organization. At the same time it will develop a holistic understanding of the needs and demands of new working conditions, behavior attitudes in a modern innovative environment (Zlatko \& Vojko, 2013, pp. 37-38).

The main obstacles facing those poorly innovative organizations are:

1) outdated values/culture/ethics/norms (VCEN) of organizational members, and especially those of management (Newman \& Nollen, 1998, pp. 57, 109; Nedelko, 2011),

2) lack of innovative culture (Potocan \& Mulej, 2007),

3) negative attitudes towards risk and unwillingness to take risk (Rebernik et al., 2001-2010),

4) one-sided understanding of innovativeness (Buc ${ }^{\nu}$ ar \& Stare, 2002), while innovativeness is often limited only on technical-technological innovations (Mulej, 1994, p. xiv),

5) underdeveloped service sector and public administration (Bučar \& Stare, 2002),

6) low efficiency of investments in research and development and weak cooperation between private/public sector organizations and research institutions (Stanovnik \& Kovac`ič ${ }^{`}$, 2000; Mulej, 2007);

7) management does not see entrepreneurship activities as an opportunity for organizational development (Newman \& Nollen, 1998, p. 37).

\section{Methodology}

The task of collecting the relevant data and using the most suitable method for data analysis, is an essential factor in undertaking a field study. Beyond literature review, a questionnaire is one of the most commonly used tool for data collection. Therefore, it was used as the main tool of data collection for this study.

A literature review was conducted to specify related concepts and to formulate the theoretical framework of the study. Different types of statistical tests were conducted such as (Cronbach's Alpha, Regression analysis, ANOVA analysis, and correlation Coefficient) to determine the impact of independent variables on dependent variables.

\subsection{The Questionnaire}

Based on the related literature review, a questionnaire was designed. It comprises four parts measuring the sample general characteristics, independent variables and dependent variables. It was reviewed by 5 academics referees before it was finalized and distributed. To assure the internal consistency and reliability of the questionnaire, Cronbach's Alpha test was carried out and the related results shown in (Table 1) clearly indicate that the questionnaire statements are consistence and it is reliable for further statistical analysis.

Table 1. The results of Cronbach's Alpha test

\begin{tabular}{ll}
\hline The Variables & Cronbach's Alpha \\
\hline Independent (X1): The University Managerial process that handle the entrepreneurial & 0.86 \\
adoption problems and obstacles & \\
Independent (X2): The University general managerial and financial Policies & 0.935 \\
Independent (X3): Managerial staff awareness of entrepreneurial concept & 0.91 \\
Dependent (Y1): university expansion & 0.85 \\
Dependent (Y2): The Consolidation of university competitive advantage. & 0.87 \\
\hline
\end{tabular}

\subsection{The Sample of the Study}

A random sample of 320 managerial staff members of different managerial levels was drawn from eight Jordanian universities (i.e., 40 questionnaires per university). Thusly, 320 questionnaires were distributed and 
239 were completed and returned with a response rate of $74.68 \%$. Table 2 portrays the questionnaire distribution and return. Sample Characteristics are presented in (Table 3).

Table 2. Questionnaire distribution and return

\begin{tabular}{llll}
\hline Type & University & Questionnaire Distributed & Questionnaire completed and return \\
\hline \multirow{6}{*}{ Private } & Al Zaytoonah & 40 & 31 \\
& Jadara & 40 & 29 \\
& Petra & 40 & 27 \\
& Israa & 40 & 33 \\
& Jerash & 40 & 29 \\
& Total & 200 & 149 \\
\hline \multirow{4}{*}{ Public } & Jordan & 40 & 26 \\
& Yarmouk & 40 & 29 \\
& Mutha & 40 & 35 \\
& Total & 120 & 90 \\
& Grand Total & 320 & 239 \\
\hline
\end{tabular}

Table 3. Sample characteristic

\begin{tabular}{llll}
\hline Description & Category & Frequency & Percentage \% \\
\hline \multirow{3}{*}{ Sex } & Male & 177 & 74 \\
& Female & 62 & 26 \\
& Total & 239 & $100.00 \%$ \\
\hline \multirow{3}{*}{ Material status } & Married & 213 & 89 \\
& Single & 26 & 11 \\
& Total & 239 & $100.00 \%$ \\
\hline \multirow{3}{*}{ Entrepreneurship Experience } & 20-39 years & 91 & 38 \\
& over 40 years & 148 & 62 \\
& Total & 239 & $100.00 \%$ \\
\hline \multirow{3}{*}{ Level of Education } & With & 220 & 92 \\
& Without & 19 & 8 \\
& Total & 239 & $100.00 \%$ \\
\hline \multirow{3}{*}{ Tenure } & Bachelor & 208 & 87 \\
& Master & 19 & 8 \\
& Ph.D. & 14 & 6 \\
& Total & 239 & $100.00 \%$ \\
\hline & $1-5$ years & 29 & 13 \\
& 6-10 years & 88 & 37 \\
& over 11 years & 122 & 51 \\
& Total & 239 & $100.00 \%$ \\
\hline
\end{tabular}

\subsection{The Study Variables}

\subsubsection{Independent Variables}

First independent variable (X1): The University Managerial process that handle the entrepreneurial adoption problems and obstacles.

Second independent variable (X2): The University general managerial and financial policies.

Third independent variable (X3): Managerial staff awareness of entrepreneurial concept

\subsubsection{Dependent Variables}

First dependent variable (Y1): university expansion.

Second dependent variable (Y2): The Consolidation of university competitive advantage.

\subsection{Hypotheses of the Study}

Ho1: there is no statistically significant effect of the university managerial process that handles the entrepreneurial adoption problems and obstacles on university expansion. 
Ho2: there is no statistically significant effect of the university general managerial and financial policies on the university expansion.

Ho3: there is no statistically significant effect of managerial staff awareness of entrepreneurial concept on university expansion.

Ho4: there is no statistically significant effect of the university managerial process that handles the entrepreneurial adoption problems and obstacles on the consolidation of university competitive advantage.

Ho5: there is no statistically significant effect of the university general managerial and financial policies on the consolidation of university competitive advantage.

Ho6: there is no statistically significant effect of managerial staff awareness of entrepreneurial concept on the consolidation of university competitive advantage.

\subsection{Hypotheses Testing}

The statistical testing results (i.e., $\mathrm{R}$ values, Beta values, calculated $\mathrm{F}$ values and levels of significant) portrayed in table 4 clearly indicate that the three independent variables (X1, X2 and X3) have positive impacts individually and collectively on the independent variable Y1. These results precisely mean that the null hypotheses (Ho1, Ho2 and Ho3) should be rejected and the alternative hypotheses should be accepted.

Table 5 results (i.e., $\mathrm{R}$ values, Beta values, calculated $\mathrm{F}$ values and levels of significant) plainly denote that the three independent variables (X1, X2 and X3) individually and collectively have positive impacts on the dependent variable Y2.

These results plainly point out that the null hypotheses (Ho4, Ho5 and Ho6) must be rejected and the alternative hypotheses should be accepted.

The above mentioned results unquestionably suggest that all the null hypotheses should be rejected and the alternative hypothesis should be accepted.

Table 4. The impact indicate A

\begin{tabular}{|c|c|c|c|c|c|}
\hline \multicolumn{6}{|c|}{ Model Summary } \\
\hline Model & $\mathrm{R}$ & R Square & Adjusted R Square & \multicolumn{2}{|c|}{ Std. Error of the Estimate } \\
\hline 1 & $0.908^{\mathrm{a}}$ & 0.825 & 0.813 & \multicolumn{2}{|c|}{.24235} \\
\hline \multicolumn{6}{|c|}{ a. Predictors: (Constant), X1, X2, X3 } \\
\hline \multicolumn{6}{|c|}{ ANOVA } \\
\hline Model & Sum of Squares & Df & Mean Square & $\mathrm{F}$ & Sig. \\
\hline Regression & 12.699 & 3 & 4.233 & 72.069 & $.000^{\mathrm{a}}$ \\
\hline Residual & 2.702 & 46 & 0.59 & & \\
\hline Total & 15.401 & 49 & & & \\
\hline \multicolumn{6}{|c|}{ a. Predictors: (Constant), X1, X2, X3; b. Dependent Variable: Y1 } \\
\hline \multicolumn{6}{|c|}{ Coefficients } \\
\hline \multirow[t]{3}{*}{ Model } & \multirow{2}{*}{\multicolumn{2}{|c|}{ Unstandardized Coefficients }} & Standardized & $\mathrm{t}$ & Sig. \\
\hline & & & Coefficients & & \\
\hline & $\mathrm{B}$ & Std. Error & Beta & & \\
\hline Constant & -.061 & .280 & & -.218 & .829 \\
\hline $\mathrm{X} 1$ & .783 & .210 & 748 & 3.722 & .001 \\
\hline $\mathrm{X} 2$ & -.603 & .119 & -.739 & -5.076 & .000 \\
\hline $\mathrm{X} 3$ & .812 & .236 & .787 & 3.441 & .001 \\
\hline
\end{tabular}


Table 5. The impact indicate B

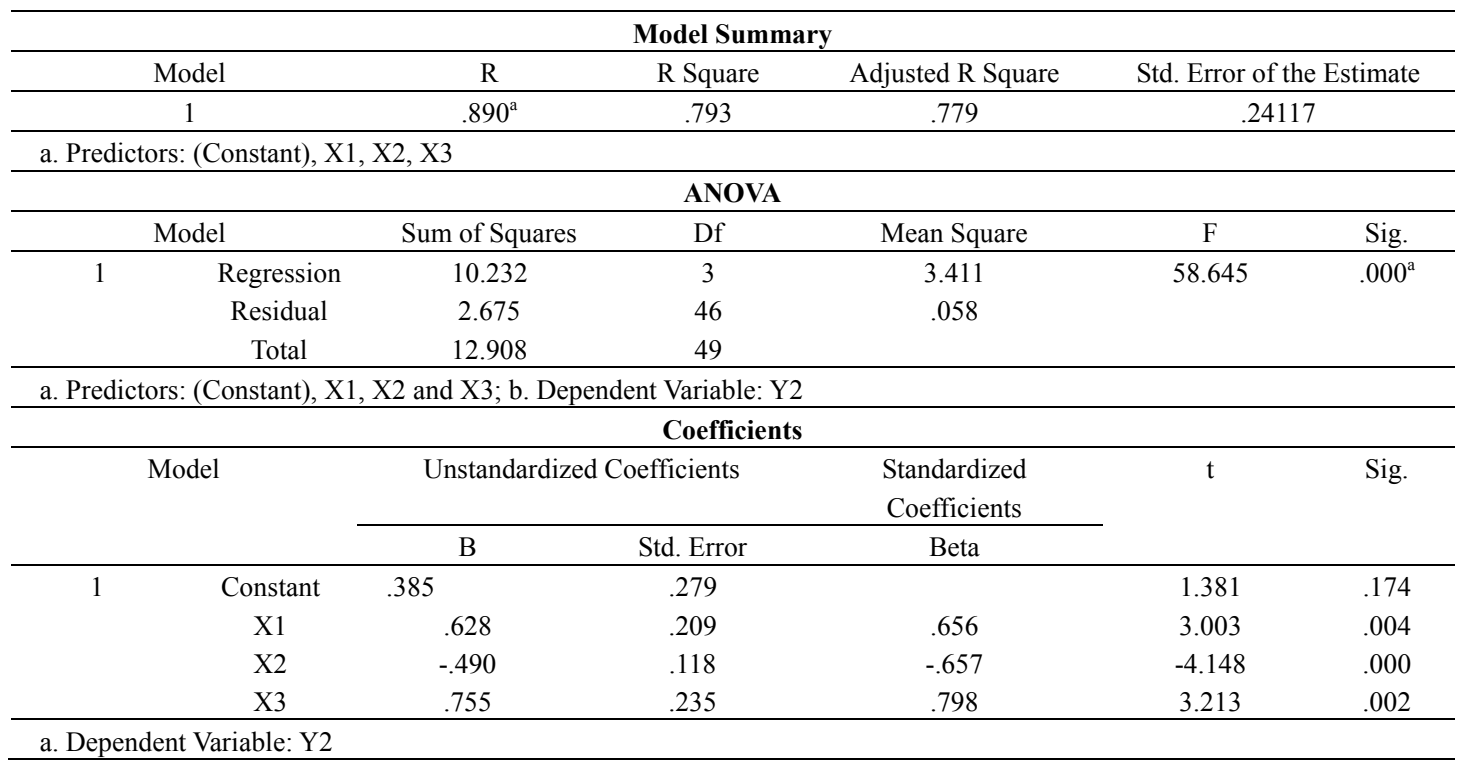

\section{Discussion}

Entrepreneurship is a common aspect in the business world and in management literature, but this is not the case for the education sector. In contrast, educational institutions in general and universities in particular are, in fact, the main originators of entrepreneurs in our societies. This is a beneficial and highly required output that the national education system is provided for our societies to maintain the necessary economic growth under a very rapidly changing and highly competitive environment. Investing in entrepreneurship implementation is a rational decision that will yield favorable outcome for individuals, educational institutions, national economy and the whole society. The results illustrated in the previous table (Table 4 and table 5) plainly indicate that the three independent variables (X1, X2 and X3) collectively and individually have a positive impact on the university expansion and on the strength of its competitive advantage.

This conclusion, obviously, would encourage universities and other educational institutions to start implementing entrepreneurship concepts in their curriculum if they have not implemented the concept yet. Educational institutions which have been already implementing the concept need to broaden their implementation to cover new areas of their curriculum. This task would be a rational practice that would yield beneficial outcomes and feasible returns for all concerned parties.

\section{References}

Abood, N., Aboyasin, N. A., \& Ajloni, M. I. (2014). Impact of the Entrepreneurial Attributes on Business Performance in a Sample of Jordanian Institutions. International Journal of Professional Management, $9(1)$.

Blenker, P., Korsgaard, S., Neergaard, H., \& Thrane, C. (2011). The questions we care about: paradigms and progression in entrepreneurship education. Industry \& Higher Education, 25(6), 417-428. http://dx.doi.org/10.5367/ihe.2011.0065

Buc`ar, M., \& Stare, M. (2002). Macroeconomic policy vs innovation policy in the transition countries. $E U$ Enlargement in a Changing World (CD edition). Institute for Economic Research, Ljubljana.

Burns, T., \& Stalker, G. M. (1961). The Management of Innovation. London: Tavistock.

Carey, C., \& Matlay, M. (2012). Emergent issues in enterprise education. Industry \& Higher Education, 25(6), 441-450. http://dx.doi.org/10.5367/ihe.2011.0067

Cho, B. (1998). Study of the effective entrepreneurship education method and its process. Business Education Research, 2(1), 27-47.

Daft, R. L. (2007). Understanding the Theory and Design of Organizations. Mason, OH: South-Western.

Dyck, R., \& Mulej, M. (Eds.). (1998). Self-transformation of the Forgotten Four-Fifth. Dubuque, IA: Kendall/Hunt. 
European Commission: Entrepreneurship Education. (2013). A Guide for Educators, Bruxelles, 2013, Foreword.

Finkle, T. A., Kuratko, D. F., \& Goldsby, M. G. (2006). An examination of entrepreneurship centers in the United States: a national survey. Journal of Small Business Management, 44(2), 184-206. http://dx.doi.org/10.1111/j.1540-627X.2006.00163.x

Garavan, T. N., \& O’Cinneide, B. (1994a). Entrepreneurship education and training programmes: a review and evaluation-part 1. Journal of European Industria Training, 18(8), 3-12. http://dx.doi.org/10.1108/03090599410068024

Garavan, T. N., \& O'Cinneide, B. (1994b). Entrepreneurship education and training programmes: a review and evaluation-part 2. Journal of European Industrial Training, 18(11), 13-21. http://dx.doi.org/10.1108/03090599410073505

Gibb, A. (2002). Creating conducive environments for learning and Entrepreneurship; living with, dealing with, creating and enjoying uncertainty and complexity. Industry and Higher Education, 16(3), 135-148. http://dx.doi.org/10.5367/000000002101296234

Gorman, G., Hanlon, D., \& King, W. (1997). Some research perspectives on entrepreneurship education, enterprise education and education for small business management: a ten-year literature review. International Small Business Journal, 15(3), 56-77. http://dx.doi.org/10.1177/0266242697153004

Hannon, P. (2004). Making the journey from student to ntrepreneur: a review of the existing research into graduate entrepreneurship. National Council for Graduate Entrepreneurship, Birmingham.

Isaac, A. G. (1998). Marx on entrepreneur. Retrieved from http://archives.econ.utah.edu

Jones, C. (2011). Teaching Entrepreneurship to Undergraduates. Cheltenham: Edward Elgar. http://dx.doi.org/10.4337/9781781002001

Jones, C., \& Matlay, H. (2011). Understanding the heterogeneity of entrepreneurship education: going beyond Gartner. Education \& Training, 53(8/9), 692-703. http://dx.doi.org/10.1108/00400911111185026

Lee, S. M., \& Peterson, S. (2000). Culture, entrepreneurial orientation, and global competitiveness. Journal of World Business, 35, 401-416. http://dx.doi.org/10.1016/S1090-9516(00)00045-6

Lee, S. M., Chang, D., \& Lim, S. (2005). Impact of Entrepreneurship Education: A Comparative Study of the U.S. and Korea. International Entrepreneurship and Management Journal, 1(1), 27-43. http://dx.doi.org/10.1007/s11365-005-6674-2

Lewis, H. (2011). A model of entrepreneurial capability based on a holistic review of the literature from three academic domains. Industry \& Higher Education, 25(6), 429-440. http://dx.doi.org/10.5367/ihe.2011.0071

Luthje, C., \& Franke, N. (2003). The making of an entrepreneur: testing a model of entrepreneurial intention among engineering students at MIT. R\&D Management, 33(2), 135-147. http://dx.doi.org/10.1111/1467-9310.00288

Matlay, H., \& Carey, C. (2007). Entrepreneurship education in the UK: a longitudinal perspective. Journal of Small Business \& Enterprise Development, 14(2), 252-263. http://dx.doi.org/10.1108/14626000710746682

Mulej, M. (1994). Innovating Management, EPF, Maribor (in Slovene).

Mulej, M. (2006). Why in Slovenia there is still not enough innovating-economic and cultural development reasons. Our Economy, 52(3/4), 39-48 (in Slovene).

Mulej, M. (2007). Innovating Habits of Country and Small Enterprises with Inventions from Research Organizations, Fakulteta za management, Koper.

Mulej, M., \& Kajzer, S. (1998). Self-transformation and transition from a pre-industrial to contemporary economy and society. In R. G. Dyck \& Mulej, M. (Eds.), Self-transformation of the Forgotten Four-Fifths (pp. 325-331). Dubuque, IA: Kendall/Hunt Publishing Company.

Nedelko, Z. (2011). How to Improve Innovativeness as a Value of Management in Transition. EPF, Maribor (in Slovene).

Nedelko, Z., \& Potocan, V. (2013). The role of management innovativeness in modern organizations. Journal of Enterprising Communities: People and Places in the Global Economy, 7(1), 36-49. http://dx.doi.org/10.1108/17506201311315590

Newman, K. L., \& Nollen, S. (1998). Managing Radical Organizational Change: Company Transformation in 
Emerging Market Economies. London: Sage.

Pittaway, L., \& Cope, J. (2007). Entrepreneurship education-a systematic review of the evidence. International Small Business Journal, 25(5), 477-506. http://dx.doi.org/10.1177/0266242607080656

Pittaway, L., \& Hannon, P. (2008). Institutional strategies for developing enterprise education: a review of some concepts and models. Journal of Small Business and Enterprise Development, 15(1), 202. http://dx.doi.org/10.1108/14626000810850937

Potocan, V., \& Mulej, M. (2007). Transition into Innovative Enterprise. EPF, Maribor.

Rae, D. (2010). Universities and enterprise education: responding to the challenges of the new era. Journal of Small Business and Enterprise Development, 17(4), 591-606. http://dx.doi.org/10.1108/14626001011088741

Rae, D., Lynn, M., Antcliff, V., \& Hannon, P. (2012). Enterprise and entrepreneurship in English higher education: 2010 and beyond. Journal of Small Business and Enterprise Development, 19(3), 380-401. http://dx.doi.org/10.1108/14626001211250090

Rebernik, M. et al. (Eds.). (2001-2010). Global Entrepreneurship Monitor: Slovenian Entrepreneurship Observatory. EPF, Maribor.

Rifai, F. (2015). Striving to become an entrepreneurial University to bridge the gap between knowing and doing - a study in Al-Zaytoonah University of Jordan. European-American Journals, 3(7), 47-56.

Schermerhorn, J. R. (2008). Management. Hoboken, NJ: Wiley.

Schumpeter, J. A. (1934). The theory of economic development. Cambridge, MA: Harvard University Press

Stanovnik, P., \& Kovac ${ }^{`} c^{`}$, A. (2000). Measuring competitiveness of national economies with emphasis on Slovenia. Working Paper No. 6, Institute for Economic Research, Ljubljana.

Wickham, P. A. (2001). Strategic Entrepreneurship. Harlow: Prentice Hall.

\section{Copyrights}

Copyright for this article is retained by the author(s), with first publication rights granted to the journal.

This is an open-access article distributed under the terms and conditions of the Creative Commons Attribution license (http://creativecommons.org/licenses/by/4.0/). 